\title{
O USO DO YOUTUBE COMO FERRAMENTA DE MARKETING: 0 CASO GUARANÁ ANTARCTICA
}

\author{
THE YOUTUBE AS A MARKETING TOOL: THE GUARANA ANTARCTICA'S CASE
}

\section{Thiago Carvalho Pereira}

\section{Eduardo Picanço Cruz}

\section{RESUMO}

Este trabalho tem como objetivo estudar como o site YouTube, um serviço altamente difundido e popularizado entre os usuários da internet neste início de século, tem sido utilizado pelas grandes empresas como uma eficiente ferramenta de promoção de marketing. Para isso, será utilizado como estudo de caso a marca Guaraná Antarctica e seu espaço no YouTube, bem como a difusão desta através dos usuários pela comunicação viral. Para dar base conceitual ao referido trabalho, primeiramente será abordado sobre o Marketing como ciência, sua trajetória desde os precursores até a década atual, seus principais conceitos, sua abrangência e o composto de marketing. Após isso, o artigo manterá o foco no composto de marketing Promoção, onde serão tratados o modelo do processo de comunicação e as etapas que compõem o desenvolvimento de uma comunicação eficaz. Então, será feita uma abordagem sobre mídia expondo os principais meios de comunicação e suas características, e as tendências do uso da mídia nos próximos anos. Em seguida apresentamos o YouTube, sua história, funcionalidade, repercussão e sobre as ações de marketing realizadas no mesmo. Por fim, será exposto o estudo de caso propriamente dito, que abordará a história e o marketing do Guaraná Antarctica, sua relação com o YouTube e os resultados do trabalho.

Palavras-chave: Marketing. Promoção. Mídia. Internet. YouTube. Guaraná Antarctica.

\begin{abstract}
This article examines how the YouTube site, a popular and widespread service since of the beginning of this century, has been used by large companies as an efficient tool for promotion of marketing. For this purpose, we study the Guarana Antarctica's case and its space on YouTube, and their distribution to users of viral communication. Conceptual basis to the article, starts in research on marketing as a science, its history since the precursors to the current decade, its main concepts, their scope and consists of marketing mix. After that, the article will keep the focus on promotion, which will be treated the model of the communication process and the steps to develop of effective communication. Then, we present the concepts of media, exposing the main media and their characteristics, and trends in the use of media in coming years. Introducing YouTube, its history, functionality, and the impact of marketing actions. Finally, it will be explained the case, the relationship with YouTube and the results of the work.
\end{abstract}

Key words: Marketing. Promotion. Media. Internet. YouTube. Guarana Antarctica. 


\section{INTRODUÇÃO}

Para mexer com a cabeça do consumidor moderno, não é suficiente oferecer apenas o que ele necessita, é necessário, ao apresentar o produto, construir valores em sua mente que exprimam a ideia de que, mesmo sem saber, ele necessita daquele produto, ou que aquele produto certamente trará a ele uma sensação de bem-estar ao consumi-lo.

Dessa forma, as empresas têm buscado meios eficientes de comunicação para chegar ao consumidor e mostrá-lo que seu produto promove muito mais que uma satisfação de necessidades, ele proporciona bem-estar. Um poderoso meio de comunicação que tem sido amplamente utilizado pelas empresas é a internet. Sua popularização no fim do século XX e sua consolidação e crescimento nesta primeira década do século XXI comprova que, parafraseando Vaz (2008), a internet é o meio que faltava para entender e acolher as demandas e desejos reprimidos dos consumidores, e mais: um meio onde as empresas poderiam facilmente mesclar marketing com diversão e entretenimento.

Nos últimos anos, o YouTube tem sido visto por grandes empresas como uma boa alternativa para promoção de produtos e/ou marcas. Diversas empresas se tornam parceiras do site para criar seus canais no mesmo, utilizando-se de sua principal ferramenta: a hospedagem de vídeos. Através do site, as empresas podem hospedar, por exemplo, suas propagandas a um preço muito mais baixo que o despendido em um intervalo comercial de uma emissora de televisão. Outra vantagem é que os vídeos no YouTube não necessariamente ficam retidos apenas aos tradicionais 30 segundos de propaganda das emissoras de TV.

É importante ressaltar também que, de acordo com Fusco (2008), pelo menos 11,5 milhões de brasileiros e 300 milhões de pessoas no mundo acessam o YouTube mensalmente. Com números tão expressivos, pode-se levar a crer que o YouTube, no mínimo, parece ter um ótimo campo para a promoção de produtos ou serviços. Para consolidar essas ideias, trataremos, nesse artigo, de como a AmBev promove o seu produto Guaraná Antarctica em um site de hospedagem de vídeos, denominado YouTube, que, inicialmente, tinha apenas como objetivo hospedar vídeos de pessoas comuns com o intuito de divulgar os mesmos sem nenhum cunho publicitário.

\section{MARKETING}

O marketing está presente em todo lugar. Durante a rotina diária, pessoas são bombardeadas com inúmeras atividades de marketing em seu meio social. Um exemplo disso é o número de outdoors, outbuses, placas, cartazes, dentre outros, que são vistos nas ruas anunciando produtos, serviços ou promoções dos mesmos. Indiretamente, pessoas e organizações exercem atividades socialmente que poderiam ser consideradas atividades de marketing, comprovando que ele está intrinsecamente presente na vida cotidiana das pessoas, seja nas roupas que as mesmas usam, sejam nos sites que elas acessam diariamente ou mesmo nos costumes e práticas as quais, aparentemente, não estão diretamente ligados às atividades de marketing.

A American Marketing Association (apud. KOTLER; KELLER, 2006), define marketing da seguinte forma:

Marketing é uma função organizacional e um conjunto de processos que envolvem a criação, a comunicação e a entrega de valor para os clientes, bem como a administração do relacionamento com eles, de modo que beneficie a 
organização e seu público interessado.

No entanto, pode-se definir marketing como mais que uma função organizacional. Conforme exposto por Kotler e Keller (2006, p.4), "podemos estabelecer definições diferentes de marketing sob as perspectivas social e gerencial". Ainda segundo esses autores, mais que uma função organizacional, marketing é um processo social, no qual pessoas ou grupo de pessoas conseguem obter o que necessitam através da criação, oferta e negociação de produtos e serviços.

Pode-se acrescentar ainda que o marketing é fruto de um relacionamento organizaçãosociedade, e, como qualquer relação de troca, não surge do nada. As ações de marketing bem planejadas são o diferencial para que o cliente opte por um produto na prateleira do supermercado em detrimento de outro. 0 marketing não se baseia apenas no curto prazo, nem tampouco é inerte.

\section{COMPOSTO DE MARKETING}

0 marketing integrado sustenta a ideia de que as atividades de marketing devem ser delineadas de forma integrada para gerar valor aos clientes. A combinação dos elementos variáveis das atividades de marketing é a definição do que chamamos Composto de Marketing, ou Marketing Mix, ou até mesmo "4P's do Marketing". De acordo com McCarthy (1996), o composto de marketing é dividido em quatro grandes grupos: (i) Produto (Product) - que é algo oferecido a um mercado com intuito de satisfazer suas necessidades; (ii) Preço (Price) - é quanto vale o produto para o consumidor, não apenas o valor monetário, mas também o custo de oportunidade para o mesmo ser adquirido; (iii) Promoção (Promotion) - é qualquer ação que visa elevar o status de um determinado produto, de modo que ele seja atrativo para aquisição; e (iii) Praça (Place) - ações necessárias para apresentar o produto ao consumidor, possibilitando-o de comprar ou consumir o mesmo.

Podemos elencar as atividades de cada "P" do composto de marketing conforme quadro:

Quadro 1: Principais atividades de cada composto de marketing

\begin{tabular}{|c|c|c|c|}
\hline Produto & Preço & Promoção & Praça \\
\hline $\begin{array}{l}\text { - Diferentes tipos de } \\
\text { design } \\
\text { - Características } \\
\text { - Diferenciais com a } \\
\text { concorrência } \\
\text { - Marca } \\
\text { - Especificações } \\
\text { - Política de garantia } \\
\text { - Embalagem }\end{array}$ & $\begin{array}{l}\text { - Financiamentos } \\
\text { - Condições de } \\
\text { pagamento } \\
\text { - Prazo médio } \\
\text { - Número de prestações } \\
\text { - Descontos } \\
\text { - Crediário }\end{array}$ & $\begin{array}{l}\text { - Propaganda } \\
\text { - Publicidade } \\
\text { - Relações Públicas } \\
\text { - Trade Marketing } \\
\text { - Promoções de Venda } \\
\text { - Etc. }\end{array}$ & $\begin{array}{l}\text { - Lojas } \\
\text { - Canais de } \\
\text { distribuiçãa } \\
\text { - Logística } \\
\text { - Armazenamento } \\
\text { - Distribuição }\end{array}$ \\
\hline
\end{tabular}

Fonte: Serrano (2006), disponível em

<http://www.portaldomarketing.com.br/Artigos/4_Ps_do_Marketing.htm> 


\section{PROMOÇÃO}

Segundo Kotler e Keller (2006), promoção - ou comunicação - de marketing pode ser definida por: [...] o meio pelo qual as empresas buscam informar, persuadir e lembrar os consumidores - direta ou indiretamente - sobre os produtos e marcas que comercializam. Num certo sentido, a comunicação de marketing representa a 'voz' da marca e é o meio pelo qual ela estabelece um diálogo e constrói relacionamentos com os consumidores. (KOTLER; KELLER, 2006, p. 532)

O grande problema das empresas não está em fazer o cliente conhecer seus produtos ou serviços, e sim em como, quando e em que frequência fazê-lo, quais os canais corretos utilizar e a quem direcionar. Segundo Grönroos e Rusbinstein (1986), existem cinco tipos de comunicação:

- Comunicação em massa - sistema de comunicação num único sentido e sem a personalização conforme o desejo individual;

- Comunicação pessoal - comunicação onde há personalização, o emissor tem contato direto com o receptor, e há também a possibilidade imediata de feedback;

- Comunicação dirigida - é especialmente preparada para um público específico onde há a personalização estratégica para cada um dos receptores;

- Comunicação interativa - permite a interação entre o emissor e o receptor, como é o caso do uso da internet;

- Ausência de comunicação - não há relação entre emissor e receptor, portanto, não há conhecimento do produto.

\section{MÍDIA}

O termo mídia é proveniente do latim media, plural de médium, que significa "aquele que está no meio". Foi adotado pela língua portuguesa através da pronuncia do termo em inglês (media). Em termos gerais, designa todos os meios de comunicação, ou seja, os meios utilizados pelo emissor para que sua mensagem chegue de forma satisfatória ao receptor. Para dar base a este trabalho, conceituamos mídia como os possíveis meios de comunicação utilizados pelas empresas que se munem da publicidade e/ou da propaganda para expor seus produtos, serviços ou marcas para o público-alvo.

\section{MEIOS DE COMUNICAÇÃO}

Quanto à classificação, os meios de comunicação podem ser definidos por:

- Sonoros - que utilizam recursos audíveis para transmitir a mensagem ao público- alvo. Ex: Rádio e telefone.

- Escritos - que utilizam de material impresso. Ex: jornais e revistas.

- Audiovisuais - que utilizam de áudio e vídeo para transmissão de mensagens. Ex: televisão e cinema.

- Multimídia - utilização de diversos meios simultaneamente.

- Hipermídia - meios que aplicam a multimídia em conjunto com a hipertextualidade, isto é, 
textos e informações em formato digital, onde se permite maior interação do usuário. Ex: Internet e TV digital.

\section{INTERNET}

Originada para atender interesses militares na década de 1960, a internet se tornou o fenômeno da mídia moderna neste início de século. A cada ano, milhares de pessoas se tornam adeptas deste meio, que mescla praticidade, entretenimento, interatividade e informação para seus usuários. Apenas no início de 2008, foi registrado que cerca de 800 milhões de pessoas em todo o mundo fazem uso da internet (IDG! Now, 2008).

Apesar de no Brasil a internet ainda ser utilizada de forma tímida no que tange à publicidade e propaganda, representando $2,7 \%$ na participação das ações de marketing nas mídias, um estudo realizado pela empresa Microsoft constata que, se mantido o ritmo de crescimento, a internet passará a ser a mídia favorita da população da Europa em $2010^{1}$.

O "consumidor digital" adota a prática de "quanto menos trabalho, melhor". Ou seja, por que enfrentar filas no banco se ele pode pagar todas as suas contas através de alguns cliques? Ou: para que sair para jantar, se o jantar pode chegar até ele? As reuniões - formais ou informais não precisam mais ser de corpo presente, basta apenas ter todos os envolvidos adicionados no MSN e criar uma conferência.

Por esses e outros questionamentos, e pela tendência do consumidor a convergir seu espaço a fim de poder controlar toda a comunicação ao seu redor, que as empresas têm necessitado reformular a sua forma de fazer marketing, entendendo o que o consumidor realmente adiciona em sua página de favoritos no seu navegador de internet. E não fazer como algumas empresas apelidadas de "Cristóvão Colombo" por Vaz (2008), por realizarem qualquer ação se marketing sem saber para onde, para quem e como elas vão chegar, voltando sem o feedback necessário para os gestores. Ou seja, jogar o produto nas telas do consumidor de qualquer forma e sem conhecê-lo pode acarretar certa desaprovação por parte do mesmo, afinal, ninguém quer sua tela abarrotada de spams ${ }^{2}$ oferecendo produtos que em nada têm a ver com suas reais necessidades.

Outro fator que as empresas devem prestar atenção é a atratividade dos consumidores atuais às ferramentas da Web $2.0^{3}$ e a oportunidade de promover ações de marketing por meio desses utilitários. Seguem abaixo algumas das ferramentas mais utilizadas pelo usuário da web, cabendo ressaltar que, para dar base ao referido estudo, a ferramenta YouTube será mencionada no próximo capítulo.

A internet influenciou de maneira expressiva a maneira do consumidor se portar diante dos produtos e dos meios que lhes são oferecidos. Muitos sustentam a ideia que os consumidores não acreditam mais na mídia de massa, e que esperam que, não mais a empresa, mas pessoas alheias a ela lhes digam se o produto é realmente bom. E com a internet, através de seus milhares de blogs e fóruns que tratam da funcionalidade e das opiniões positivas e negativas de quase todos os produtos, o consumidor fica munido de informações que transcendem o simples "vender o peixe" visto nas propagandas tradicionais.

De acordo com os escritos de Vaz (2008), as redes sociais, a web 2.0, o marketing de permissão, a customização e a informação como geradora de valor serão tão presentes em nossa sociedade daqui a algum tempo que as pessoas não conseguirão se imaginar em outra realidade diferente. E mais: olhando para o século passado, se perguntarão como as pessoas 
daquela época viviam de maneira tão primitiva, tendo, por exemplo, que "esperar um comercial de TV acabar para que continuasse a ver o seu filme" (VAZ, 2008, p. 414).

Outra palavra que será atuante no futuro da mídia é a convergência. Aliás, um processo que já começa a acontecer, como o caso das web rádios, da TIVO - a TV pela internet -, das notícias que chegam em tempo real através da web e das novas formas de comunicação e marketing em geral. Por fim, as mídias tradicionais terão que se reinventar, ou então, num futuro próximo, poderão estar extintas.

Em suma, é muito complicado prever o que poderá acontecer no futuro próximo. Parece que todos os limites da interatividade humana foram desvencilhados. Agora, nos resta saber "se estamos indo na direção certa, afinal velocidade pode ser uma péssima companheira se pegarmos a direção errada" (VAZ, 2008, p. 415).

\section{YOUTUBE}

YouTube é um website que permite aos seus usuários o compartilhamento de vídeos em formato digital. Fundado em 2005, rapidamente se tornou uma febre entre os usuários da rede, por permitir aos mesmos adicionarem vídeos sobre fatos registrados de suas vidas ou sobre seus gostos, e compartilhá-los com os demais usuários.

0 YouTube utiliza o formato Flash Player para disponibilizar o conteúdo, permitindo que os usuários assistam aos vídeos sem a necessidade de realizar o download dos mesmos. É o mais site mais popular do gênero, com mais de 50\% do mercado global em 2006. No Brasil, certamente essa porcentagem é bem maior.

Foi considerada pela revista norte-americana Time em novembro de 2006 como a melhor invenção do ano por "criar uma nova forma para milhões de pessoas se entreterem, se educarem e se chocarem de uma maneira como nunca foi vista” (G1, Nov. 2006).

Seguem algumas características do conteúdo disponibilizado pelo site:

- Vídeo e audio: Através da tecnologia Flash Player, da empresa Adobe, o site pode exibir vídeos com qualidade comparável aos tradicionais reprodutores de mídia audiovisual, como Windows Media Player, QuickTime Player e RealPlayer. Os vídeos no YouTube são reproduzidos em formato Flash Vídeo (.flv). Os usuários têm a opção de assistir aos vídeos em tela cheia ou no modo janela, podendo intercalar entre os dois modos durante a exibição sem a necessidade de novo carregamento. Os vídeos adicionados pelos usuários têm tempo limite de 10 minutos e tamanho limite de 1 GB. No lançamento do youtube, era permitido enviar vídeos com tempo maior que 10 minutos, porém essa restrição - iniciada em março de 2006 se deve ao fato de que a maioria dos vídeos que ultrapassavam esse limite provinha de conteúdo não autorizado para distribuição, como programas de televisão e filmes.

- Acessibilidade do conteúdo e interação do usuário: o YouTube aceita formatos de vídeo convencionais, como .wmv, .avi, .rmvb e outros, e converte os mesmos para o formato .flv (Flash Video). Além de poder visualizar os vídeos no próprio site, graças ao código HTML Hyper Text Markup Language - agregado a cada vídeo os usuários podem adicioná-los em outras páginas. As pessoas podem agregá-los em blogs, sites pessoais e até mesmo colocá-los como vídeos favoritos em seus perfis no site Orkut, ações essas popularmente conhecidas como embed. Por causa dessa acessibilidade ao serviço que muitos vídeos acabaram atingindo enorme popularidade entre os internautas, e isso facilita muito a divulgação de certas idéias e conceitos. 0 site permite que além de assitir os usuários podem avalia-los, postar comentários 
sobre eles e avaliar os comentários de outros usuários como bons ou ruins, além de poder visitar o perfil da pessoa que o enviou e assistir aos vídeos que estão relacionados com o exibido.

\section{COMUNICAÇÃO VIRAL}

Como característica principal, o YouTube é feito pelos usuários. Tanto a popularidade quanto o conteúdo do site é proporcionado por aqueles que utilizam e são fiéis ao serviço. Por causa disso, muitos vídeos referentes a grandes empresas que circulam pelo YouTube são provenientes da comunicação viral, aliás, é um ambiente bem propício para tal.

Comunicação viral - ou marketing viral -, nada mais é do que tornar o próprio consumidor em veículo (VAZ, 2008). Ou seja, o próprio usuário do YouTube posta materiais referentes a certas marcas, produtos ou empresas os quais ele se identifica ou teve alguma boa experiência com as mesmas ou com seus referidos materiais. Esse tipo de comunicação pode ser intencional ou não por parte da empresa, conforme ressaltado por Vaz (2008), pode ser planejada ou não.

A comunicação viral, em primeiro lugar, parte do princípio do marketing de permissão. Para definir este último, podemos utilizar a seguinte ilustração: João é um tipo de pessoa que muda de canal quando está passando o intervalo comercial e não se prende aos apelos mirabolantes da mídia convencional. Odeia spams, os quais apaga de sua lista de e-mails sem ao menos ler. Porém, quando um amigo seu lhe envia um vídeo do YouTube que contenha um conteúdo promocional atrativo - engraçado ou criativo, por exemplo -, João recebe e assiste de bom grado. Com isso, podemos concluir que o marketing de permissão consiste em utilizar artifícios de enviar a mensagem ao consumidor através de fontes que o mesmo considera confiáveis - no caso do João, o seu amigo que enviou o e-mail. A empresa não diz diretamente que o seu produto ou a sua promoção são bons, ela deixa que os próprios consumidores que tiveram boas experiências com ela digam para os outros que o produto é realmente bom. Os consumidores têm acreditado muito mais em experiências positivas de seus pares do que em apelos emocionantes da comunicação tradicional. E isso dá um "quê" de credibilidade à comunicação viral.

Outro ponto é que empresas que utilizam desse método são consideradas desbravadoras da comunicação, explorando um meio não-convencional de atingir seu público, de uma maneira que não é vista entre as grandes e dispendiosas mídias tradicionais.

Proposital ou não, a comunicação viral tem se tornado uma grande aliada das empresas e o YouTube tem se constituído como uma poderosa ferramenta para proporcioná-la, fazendo com que as empresas que abraçam essa ideia assumam uma postura do tipo: "eu não quero dizer o quanto eu sou bom, vou deixar que o meu público fale por mim." Se o produto é realmente bom, o público vai dizer, se não, eles também o farão. Um caso onde a empresa vê na comunicação viral uma ótima oportunidade de promoção foi citado por Vaz (2008), conforme abaixo: Nick Haley, de 18 anos, um estudante inglês e fã da Apple produziu um comercial para o iPod Touch, com a música "Music is My Hot, Hot Sex" da banda brasileira "Cansei de Ser Sexy" e o postou no YouTube. Até aí, tudo bem. O fato é que o comercial chamou a atenção da própria Apple que resolveu, juntamente com Haley, produzir o comercial profissionalmente. (VAZ, 2008, p. 286)

Esse é um de muitos outros exemplos em que empresas, marcas, produtos ou pessoas são promovidos por meio da comunicação viral. E essa tende a se tornar fundamental quando 
falamos em consumidores que não confiam mais nas instituições ou na grande mídia e passam a dar credibilidade a pessoas que em nada tem a ver com essas, pelo menos diretamente. Afinal, a indicação de um produto por um amigo tem muito mais efeito do que todas as propagandas que um canal de televisão possa veicular a respeito do produto.

0 que as empresas que desejam iniciar esse método devem colocar em mente é que a comunicação não surge do nada e muito menos depende da sorte. Para cativar o consumidor, os profissionais de marketing devem entender o que o público quer, devem saber quem irá divulgar o material, e o que realmente vai gerar valor para a empresa.

\section{CASO GUARANÁ ANTARCTICA}

Conforme exposto o YouTube possui características e recursos que podem proporcionar às empresas uma grande chance de promover seus produtos ou serviços, ou até mesmo consolidar suas marcas. Com base nessa assertiva, neste capítulo será apresentado o estudo de caso da marca Guaraná Antarctica, promovida pela empresa AmBev, e como ela tem utilizado o YouTube como ferramenta de promoção de marketing, e também como os usuários estão promovendo a marca através da comunicação viral, planejada ou não.

\section{MARKETING DO GUARANÁ ANTARCTICA}

Como se trata de uma marca sólida e consolidada no mercado, as ações de marketing do Guaraná Antarctica visam fortalecer e manter fixa a mesma no mercado, criando propagandas que agreguem conceitos ao produto e promoções e eventos que corroborem a visibilidade da marca. Sendo assim, o Guaraná Antarctica atua com ações de marketing nas seguintes frentes:

- Patrocínio - desde 2001, a AmBev assinou um contrato com a Confederação Brasileira de Futebol, se tornando a patrocinadora oficial da seleção principal de futebol brasileira, tanto masculina quanto feminina, até $2019^{4}$.

- Propaganda - como forma de consolidar a marca e firmar a credibilidade da mesma no mercado, as propagandas do Guaraná Antarctica são relacionadas a garotos-propaganda, celebridades que participam dos intervalos comerciais.

Desde a Copa do Mundo de 2002, a Antarctica contratou o jogador de futebol Ronaldo para promover o produto, e, em 2008, assinou contrato de três anos com a cantora Cláudia Leitte e com o cantor Toni Garrido.

- Eventos - Em 2004 e 2005 houve a Copa Guaraná Antarctica, campeonato de futebol entre escolas promovido pela marca. E desde 2007, a marca promove o GAS Festival (Guaraná Antarctica Street Festival), com shows de bandas famosas e emergentes e apresentações de esportes radicais. Em 2008, a marca promoveu o programa GAS Sound, pela emissora de televisão RedeTV!, sendo considerado o maior concurso de bandas do Brasil.

\section{GUARANÁ ANTARCTICA E O YOUTUBE}

Conforme mencionado neste trabalho, muitas grandes empresas e grandes marcas têm se aproveitado do YouTube e sua popularidade para se promoverem.

Com o Guaraná Antarctica não podia ser diferente. Além de utilizar de espaço próprio no site para se promover, a marca, por ser amplamente conhecida e ter certa credibilidade no mercado, conta com uma forte comunicação viral no YouTube, seja ela iniciada pela empresa 
ou não.

Sendo assim, o intuito desse trabalho é fazer uma análise de como a marca Guaraná Antarctica está sendo divulgada no site, tanto por meios oficiais como nãooficiais, e traçar o perfil do conteúdo que é exibido no YouTube que é relacionado diretamente com a marca.

\section{CANAL DO GUARANÁ ANTARCTICA NO YOUTUBE}

A parceria do Guaraná Antarctica com o YouTube começou em 28 de julho de 2006, quando a marca criou uma conta de Patrocinadora no site, obtendo então um canal personalizado do Guaraná Antarctica no mesmo, conforme figura:

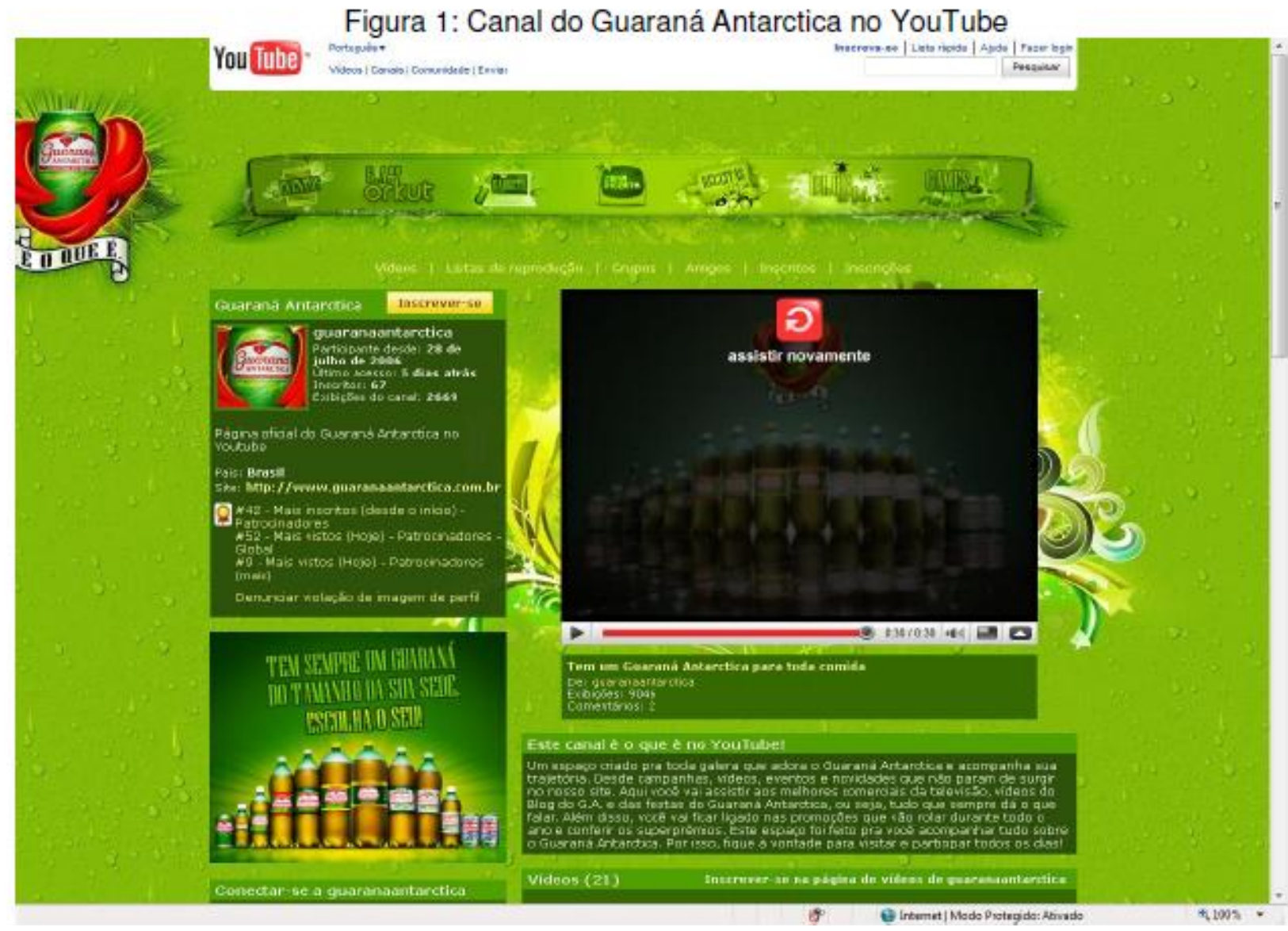

Fonte: Canal do Guaraná Antarctica - http://www.youtube.com/guaranaantarctica

Nesse espaço, segundo a própria descrição do canal, a empresa pretende divulgar campanhas, eventos, propagandas de televisão e vídeos do blog do Guaraná Antarctica e permitir a interação dos usuários com os idealizadores do canal.

Desde o lançamento no YouTube, o canal possui 21 vídeos postados, totalizando 78.093 exibições, 67 inscritos, 21 amigos, 9 comentários e 2669 exibições do canal. Os vídeos totalizam 20 comentários e a exibição dos mesmos em outros sites que não sejam no YouTube totalizam 60.192 visualizações ${ }^{5}$. 
No layout da página, existe um link que direciona pro site oficial do Guaraná Antarctica. No topo da página, existem ícones que também direcionam para o site oficial, mas para conteúdos específicos, ou para sites onde a marca é relacionada. Os ícones são:

- Eventos - direciona para a página do Guaraná Antarctica onde são divulgados os principais eventos (GAS Festival, GAS Sound, etc.);

- G.A. no Orkut - direciona para a página de pesquisas do Orkut, onde são relacionadas todas as comunidades referentes ao Guaraná Antarctica, como "Eu adoro Guaraná Antarctica" e "Queremos Guaraná Antarctica de 20 litros";

- Gadgets - direciona para o site oficial na seção de aplicativos referentes ao Guaraná Antarctica, como emotions para Messenger e músicas;

- Zona Incerta - direciona para o evento Zona Incerta (já finalizado), um jogo de ARG promovido pelo Guaraná Antarctica, e que será oportunamente detalhado mais a frente;

- Receitas - direciona para o site oficial onde são divulgadas diversas receitas tendo o Guaraná Antarctica como ingrediente;

- Blog do G.A. - direciona para o blog oficial da marca;

- Games - direciona para a área de entretenimento do site oficial, onde são hospedados jogos clássicos, como o Pac-Man.

Em 2 de junho de 2009, o Guaraná Antarctica estava em $42^{\circ}$ no ranking dos canais Patrocinadores mais inscritos, e estava em nono lugar entre os canais de Patrocinadores mais vistos no Brasil, e em $52^{\circ}$ entre os mais vistos desse gênero no âmbito global.

Para traçar o perfil dos vídeos que o Guaraná Antarctica postou no YouTube em seu canal oficial até a referida data, foi feita a classificação dos mesmos em dois grupos: propagandas da TV e conteúdo exclusivo da web - seja do site oficial ou do blog -, ressaltando que todos os resultados obtidos nesse estudo têm como base os dados obtidos no canal em 2 de junho de 2009. Vide resultado:

Gráfico 1: Classificação dos vídeos do Guaraná Antarctica postados no canal

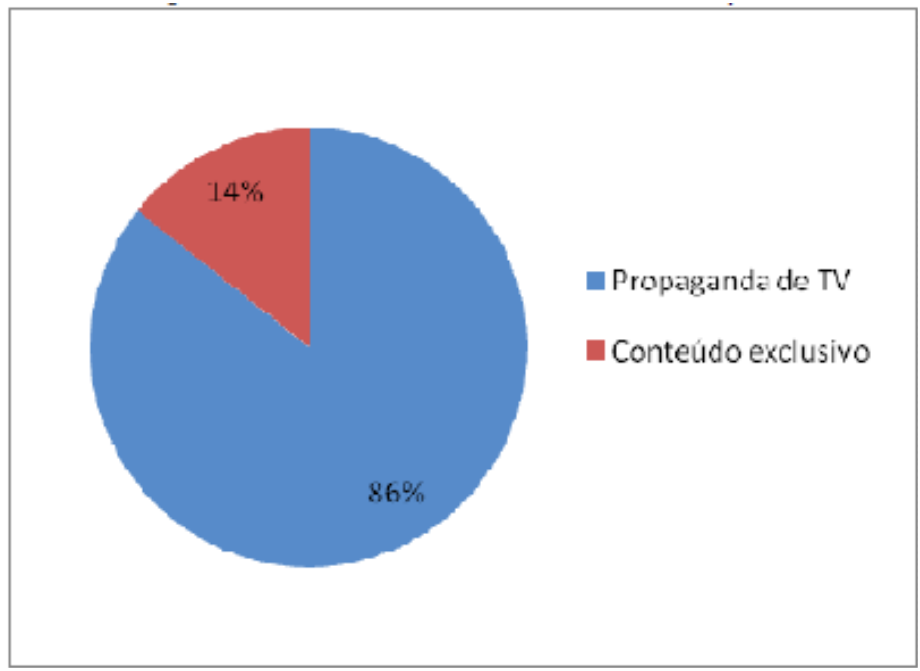

Fonte: Desenvolvimento próprio 
Conforme gráfico acima, a maioria dos vídeos postados - 18 vídeos - são propagandas de TV que a empresa disponibilizou para o site, sendo apenas 3 vídeos oriundos de conteúdo da web. Com isso, pode-se verificar que o foco da empresa é não apenas limitar as propagandas promocionais ao veículo tradicional, que é a televisão. As vantagens dessa ação são: (i) a exibição da propaganda em um canal com um custo consideravelmente baixo se comparado à exibição da mesma em horário nobre numa emissora de TV; e (ii) o fato da propaganda obter uma vida útil bem maior que a disponibilizada na televisão. Ou seja, se as propagandas duram, em média, dois meses sendo exibidas na TV, no canal do Guaraná Antarctica podem ser encontradas propagandas adicionadas a mais de 6 meses e que podem ser acionadas pelos usuários a qualquer momento. Outra grande vantagem é que os vídeos adicionados pelo Guaraná Antarctica em seu canal possibilitam a interatividade do consumidor, ou seja, através dos comentários, os internautas podem elogiar as propagandas e sugerirem ou reclamarem a respeito de algo relacionado, e o moderador do canal pode respondê-los simultaneamente.

Depois de verificar que o material disponibilizado pelo Guaraná Antarctica em seu canal oficial no YouTube é basicamente referente à propagandas já exibidas na televisão, agora será feita uma análise para identificar quais tipos de propagandas estes vídeos se referem. Para isso, será utilizada a classificação dos vídeos nos seguintes grupos: promoção, eventos, portfólio de embalagens, novo produto, patrocínio e consolidação da marca. 0 resultado se deu conforme gráfico 2 .

Gráfico 2: Classificação das propagandas postadas quanto ao gênero

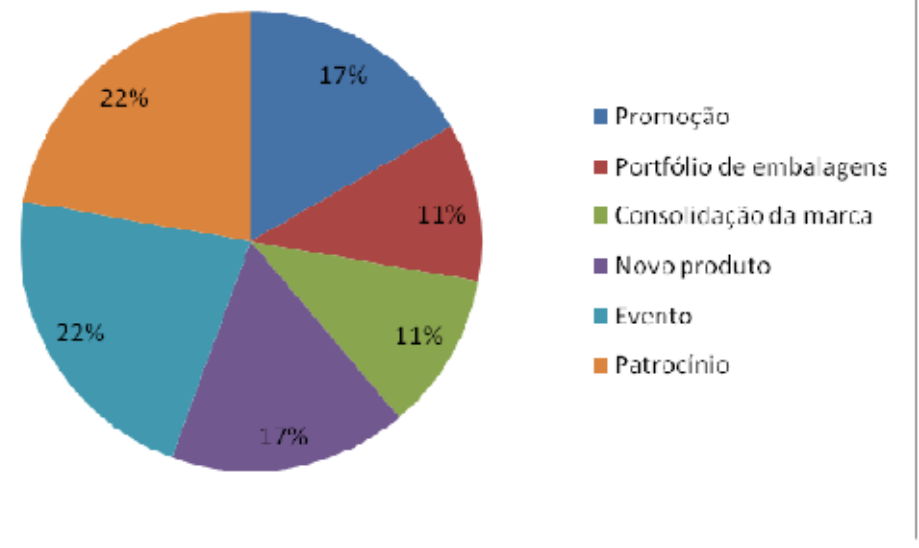

Fonte: desenvolvimento próprio

Conforme verificado, os vídeos adicionados pelo Guaraná Antarctica em seu canal no YouTube são bem diversificados quanto ao gênero, obtendo maior percentual os vídeos de eventos como o GAS Sound e o GAS Festival - e os vídeos de patrocínio - propagandas que fazem alusão à seleção brasileira de futebol.

A próxima análise é verificar qual o gênero mais procurado pelos usuários do YouTube, considerando o número de exibições de cada vídeo. 0 resultado foi explicitado no gráfico 3:

Gráfico 3: Total de exibições por gênero 


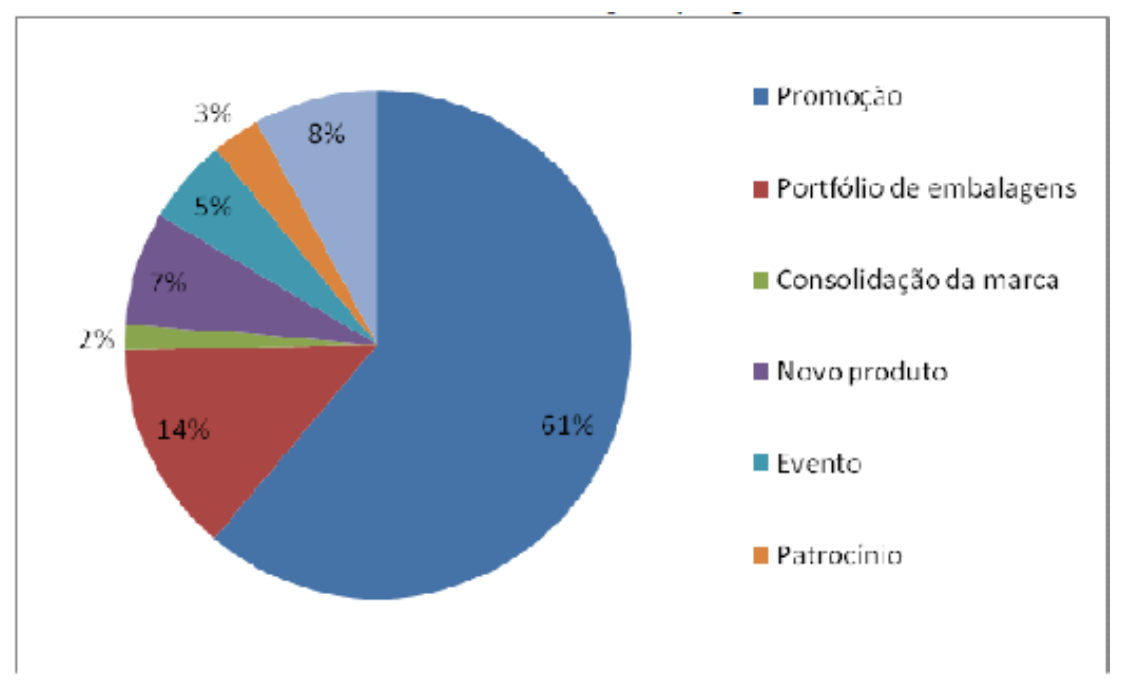

Fonte: Desenvolvimento próprio

Apesar de estarem em maior número no canal, os vídeos dos gêneros Evento e Patrocínio obtiveram percentuais pouco expressivos - 5\% e 3\%, respectivamente - na busca por vídeos do Guaraná Antarctica por parte dos usuários. Curiosamente, os vídeos relacionados a promoções foram expressivamente os mais procurados pelos internautas, com destaque para o vídeo referente à promoção Sonzera ${ }^{6}$ que, sozinho, obteve 46.763 exibições.

Através dessas informações, aliadas à ferramenta YouTube Insight - já mencionada neste trabalho -, o Guaraná Antarctica pode traçar o perfil das pessoas que se interessam pela marca no YouTube, receber o feedback das mesmas através dos comentários tanto nos vídeos quanto no próprio canal, e envidar esforços para planejar ações de marketing específicas para esse público.

\section{COMUNICAÇÃO VIRAL DO GUARANÁ ANTARCTICA NO YOUTUBE}

Após analisar como o Guaraná Antarctica se promove no YouTube pelo seu canal oficial, nesta etapa será verificado como a marca é divulgada pelos demais usuários, que não possuem vínculo direto com a empresa. Essa etapa será dividida em duas partes: primeiramente, serão analisados os conteúdos disponibilizados pelos usuários que se caracterizam numa comunicação viral não planejada pelo Guaraná Antarctica. Após isso, será analisado o caso Zona Incerta, uma promoção do Guaraná Antarctica que teve por base a comunicação viral planejada, e como foi sua repercussão no YouTube.

Para analisar a comunicação viral não planejada, foi realizada uma pesquisa de vídeos no site através das palavras-chave "Guaraná Antarctica". Ao aparecer o resultado, foi definida a ordem dos vídeos pelo número de exibições. Como os vídeos mais assistidos do Guaraná Antarctica possuíram um público bastante satisfatório e pelo fato do resultado da pesquisa apresentar um total de 545 vídeos, essa análise se limitou aos 10 primeiros vídeos, considerando os que realmente tinham o Guaraná Antarctica como fator chave e desconsiderando os vídeos que foram postados pelo canal oficial da marca.

Feita a análise, foi constatado que os 10 vídeos apresentaram um total 1.001 .088 exibições, 872 comentários e 98.575 exibições em outros sites que permitem hospedar vídeos do YouTube. Destaque para o primeiro lugar, o vídeo "Guaraná Antarctica Maradona" - que consiste numa propaganda veiculada pelo Guaraná Antarctica em 2006 que mostra o jogador Maradona sonhando que estava jogando pela seleção brasileira -, que sozinho obteve 554.656 
exibições, 398 comentários e 93.361 exibições em outros sites.

Após isso, foi feita uma análise quanto aos gêneros dos vídeos postados. Neste estudo, foram adotados três gêneros diferentes para análise:

- Propaganda - comerciais de TV que os usuários postaram no YouTube;

- Conteúdo da web - trata-se dos materiais produzidos pelo Guaraná Antarctica, mas que não foram disponibilizados na TV, tais como materiais do blog do Guaraná Antarctica, making of de propagandas e outros;

- Amador - pessoas que gravaram vídeos amadores utilizando o Guaraná Antarctica.

0 resultado da classificação se deu conforme apresentado em gráfico 4:

Gráfico 4: Classificação dos vídeos virais por gênero

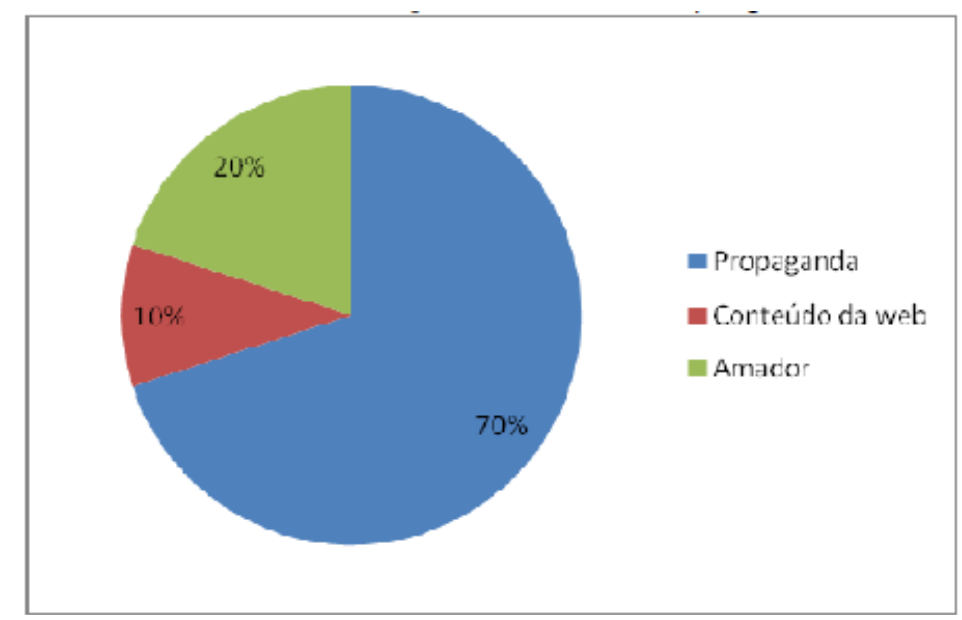

Fonte: Desenvolvimento próprio

Ou seja, a maior parte dos vídeos postados pelos internautas se refere a propagandas já veiculadas ou em veiculação na TV, sendo $20 \%$ conteúdo amador e $10 \%$ conteúdo exclusivo da web.

Como propaganda foi o gênero mais recorrente na análise, optou-se por fazer a classificação das mesmas em subgêneros, a saber:

- Patrocínio - propagandas veiculadas referentes à seleção brasileira de futebol;

- Evento - divulgação de eventos promovidos pelo Guaraná Antarctica;

- Conceito - propagandas que exibam conceitos que são atrelados ao Guaraná Antarctica, como por exemplo, um slogan ou um bordão;

- Antigo - adição de propagandas ou campanhas antigas. Serão consideradas antigas as propagandas que possuírem mais de 15 anos desde sua última exibição;

- Sátira - propagandas que tenham como conteúdo sátiras a outras marcas concorrentes.

Dessa forma, as propagandas postadas foram classificadas conforme: 
Gráfico 5: Classificação das propagandas post

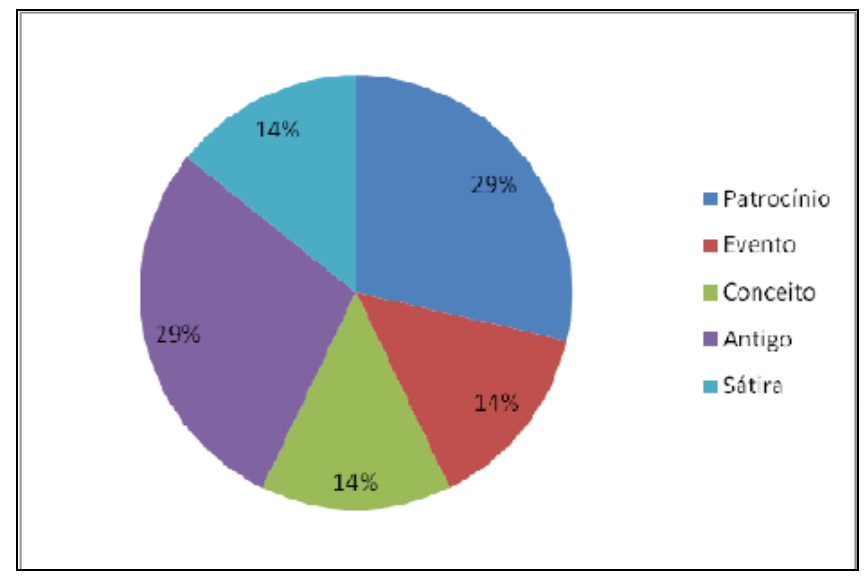

Fonte: Desenvolvimento próprio

Essas análises foram realizadas para que se tenha uma visão geral do perfil dos vídeos selecionados. Abaixo segue uma análise dos vídeos por visualização, ou seja, o gráfico abaixo irá nos permitir enxergar qual o gênero de vídeos mais procurado e mais assistido pelos usuários do YouTube em que é utilizada a marca Guaraná Antarctica. Vide:

Gráfico 6: Gêneros de vídeos virais mais procurados no YouTube

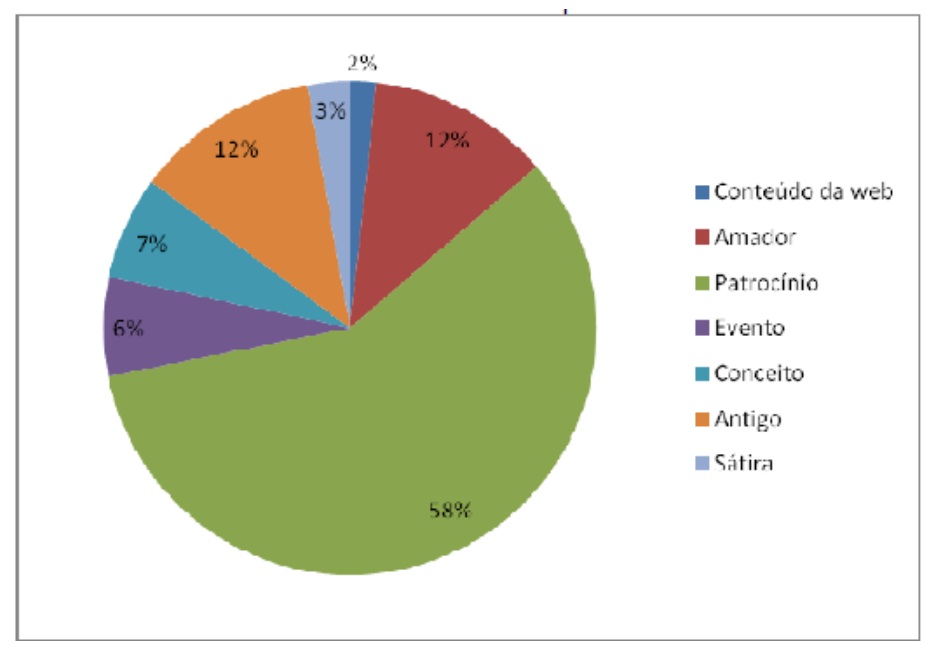

Fonte: Desenvolvimento próprio

Pelo gráfico acima, pode-se perceber que o maior número de visualizações se deu nos vídeos do gênero patrocínio, graças ao já mencionado vídeo sobre o Maradona. Pode-se perceber também que os usuários procuraram bastante os comerciais antigos e os vídeos feitos pelos próprios usuários, o que parece uma tendência dos internautas de fugirem um pouco do conteúdo trivial que já é exibido pelas grandes mídias de massa.

\section{COMUNICAÇÃO VIRAL PLANEJADA}

Em 2008, o Guaraná Antarctica lançou um jogo de $\mathrm{ARG}^{7}$ chamado Zona Incerta. 0 jogo narrava a história do pesquisador Miro Bittencourt que, durante seus estudos sobre a planta do guaraná, descobriu uma caixa antiga cheia de documentos em código, de 1940. A partir daí, o jogo motivou pessoas a iniciarem uma jornada para decifrar o código secreto. 
O jogo foi fruto da parceria entre o Guaraná Antarctica e o Núcleo Jovem da Editora Abril, com o propósito de mesclar realidade com ficção, usando todo o tipo de mídias para desenrolar a história. Por exemplo, os personagens tinham e-mails, páginas na internet e número de telefone.

No jogo, o personagem Miro passa a ser perseguido pela empresa fictícia Arkhos Biotech, empresa a qual Miro acusava na trama de intentar um processo de internacionalização da Amazônia, para favorecer seus interesses. Aliás, tamanha foi a repercussão do jogo que a suposta empresa foi motivo de menção no senado. 0 senador Artur Virgílio, líder do PSDB no senado, o senador Mozarildo Cavalcanti e a deputada Perpétua Almeida chegaram a discursar contra a Arkhos Biotech, esta última inclusive entrou com um requerimento para que o legislativo investigasse a empresa.

Em suma, o jogo representou uma expressiva campanha de marketing, contando inclusive com a comunicação viral. No total, foram nove websites envolvidos - incluindo o YouTube -, 29 anúncios diferentes nas revistas da Abril, 50 milhões de embalagens produzidas para a campanha, mais de 16 mil postagens em fóruns discutindo os detalhes da história, cinco meses de campanha e 350 mil pessoas trocando mais de 15 mil mensagens entre si para desvendar a elaborada trama.

No YouTube, a campanha rendeu 49 vídeos - todos virais -, com 52.365 visitas até 30 de maio de 2009.

\section{CONCLUSÃo}

Neste trabalho, tanto na abrangência conceitual como no estudo de caso apresentado, buscouse evidenciar a importância da utilização do YouTube como uma poderosa ferramenta de promoção de marketing. Haja vista o perfil do mercado atual e as iminentes tendências da convergência das mídias, muitas empresas têm adotado essa e outras fortes ferramentas da internet como aliadas nas ações de marketing, bem como a utilização do próprio consumidor como um veículo de promoção.

Através do estudo de caso apresentado, e, por conseguinte os dados nele expostos, pode-se concluir que, apesar do Guaraná Antarctica ter um canal oficial onde promove sua marca, a comunicação viral obteve números muito mais expressivos, ou seja, os vídeos virais foram muito mais procurados, mais comentados, mais avaliados e mais evidenciados no YouTube que os vídeos veiculados pelo canal do Guaraná Antarctica.

Isso comprova que, nas grandes ferramentas da internet, e principalmente no YouTube, a comunicação viral tem se tornado mais eficiente no que tange a transmitir a mensagem ao público que os meios convencionais de comunicação.

Como já foi dito, o YouTube tem uma forte característica viral pelo fato de ser formado por pessoas, em sua maioria sem nenhum vínculo profissional com marcas, produtos ou empresas.

Face ao exposto, é sugerido que os próximos acadêmicos interessados em abordar sobre marketing pela internet ou por suas ferramentas - YouTube, Orkut, Google, etc. - que abordem com maior aprofundamento sobre o marketing viral. 
Neste caso, o foco do trabalho foi abordar a ferramenta YouTube como aliada na promoção de marcas, produtos e serviços, porém os resultados deste apontaram a relevância da comunicação viral no repositório de vídeos.

Quanto ao YouTube, os resultados deste e dos trabalhos de outros acadêmicos que abordaram o assunto comprovam que a ferramenta não é mais desconhecida pelas empresas. Existem cada vez mais empresas enxergando no YouTube uma nova tendência de promoção de marketing e um novo conceito em transmissão da mensagem para o consumidor. E mais: o Y encarado pelo público como um fator de credibilidade, confrontando os consumidores com a obsolescência das mídias tradicionais e da forma como elas têm apelado para certo produto ou marca. Outrossim, as grandes empresas devem estar atentas às repercussões positivas e negativas de suas marcas, produtos ou mesmo de sua imagem, principalmente no YouTube. Tudo isso comprova que o YouTube é uma ferramenta bastante atual na promoção de marketing, e comprova também que não deve mais passar despercebido pelos profissionais de marketing, principalmente das grandes empresas.

Enfim, o consumidor moderno está por aí. As novas tendências de consumo e da forma de fazer marketing estão despontando. A cada ano, milhares e milhares de pessoas passam a fazer parte da grande rede, a internet. No mundo corporativo moderno, muito mais do que força, é necessário ter habilidade e sentir quando se deve inovar. As ferramentas também estão aí: Google, YouTube e Orkut estão ganhando novos adeptos no mundo dos negócios, formados por empresas que estão percebendo quais os meios que o público está dando credibilidade e quais as mensagens têm realmente cativado o público. Entender o que o consumidor quer, de que forma ele quer e em que intensidade ele quer está se tornando cada vez mais tangível com as ferramentas que surgem através da web. E quem não enxergar isso certamente não sobreviverá à "seleção natural" do mundo corporativo.

\section{REFERÊNCIAS BIBLIOGRÁFICAS}

ALTERNATE reality game. Disponível em: <http://pt.wikipedia.org/wiki/Arg>. Acesso em: 31 maio 2009.

BUSARELlO, Romeu. A sociedade do excedente. Maio 2008. Disponível em: <http://www.damm.com.br/pdf/Romeu_Busarello.pdf>. Acesso em: 23 maio 2009.

CANAL do Guaraná Antarctica. Disponível

<http://www.youtube.com/user/guaranaantarctica>. Acesso em: 30 maio 2009.

EBAY. Disponível em: <http://pt.wikipedia.org/wiki/EBay>. Acesso em: 30 maio 2009.

FUSCO, Camila. A verdadeira TV digital. Exame. São Paulo, ano 42, no 21, 05 nov. 2008.

G1. Revista Time elege YouTube a melhor invenção do ano. 07 nov. 2006. Disponível em: http://g1.globo.com/Noticias/Tecnologia/0 „AA1340903-6174- 363,00.html. Acesso em: 30 mai. 2009.

G1. YouTube ganha 20 horas de conteúdo a cada minuto. 21 mai 2009. Disponível em: <http://g1.globo.com/Noticias/Tecnologia/0,,MUL1162693-6174,00.html>. Acesso em: 30 maio 2009.

GO0GLE. Disponível em: <http://pt.wikipedia.org/wiki/Google>. Acesso em: 31 maio 2009

GRÖNROOS, Christian; RUSBINSTEIN, Jason L.. Administração de Marketing. São Paulo: 
Atlas, 1986.

GUARANÁ Antarctica. Disponível em: <http://pt.wikipedia.org/wiki/Guarana_antarctica>. Acesso em: 30 maio 2009.

IBGE (Org.). PNAD 2007. Disponível em: <http://www.ibge.gov.br/estadosat/temas.php?sigla=mg\&tema=pnad_2007>. Acesso em: 30 maio 2009.

IBOPE (Org.). Giro Ibope. Disponível em: <http://www.ibope.com/giroibope/capa.html>. Acesso em: 30 maio 2009.

IDG Now!. Número de pessoas que acessam a internet ultrapassa 800 milhões no mundo. São Paulo, 18 mar. 2008. Disponível em <http://idgnow.uol.com.br>. Acesso em 30 maio 2009.

KELMAN, Herbert C.; HOVLAND, Carl I.. Reinstatement of the communication in delayed measurement of opinion change. Journal of Abnormal and Social Psychology, 48, p. 327335. 1953.

KOTLER, Philip; KELLER, Kevin Lane. Administração de Marketing: A Bíblia do Marketing. Prentice Hall Brasil, 2006, 12a edição. 776p.

LEVITT, Theodore. Marketing Myopia. Harvard Business Review. 1960.

LITTLE, Arthur Dehon. Como transformar seu produto em mania. HSM Management, jan. 2005.

LUPETTI, Marcélia. Gestão estratégica de comunicação mercadológica. São Paulo: Thompson Learning, 2007.

MARKETING Disponível em: <http://pt.wikipedia.org/wiki/Marketing>. Acesso em: 23 maio 2009.

MARKETING Societal Disponível em: <http://pt.wikipedia.org/wiki/Marketing_societal>. Acesso em: 23 maio 2009.

MARKETING Viral Disponível em: <http://pt.wikipedia.org/wiki/Marketing_viral>. Acesso em: 23 maio 2009.

MCCARTHY, Jerome. Basic marketing: a managerial approach. 12. ed. Homewood: Irwin, 1996.

MICROSOFT. Estudo Microsoft prevê que uso Internet ultrapasse a Televisão já em Junho $2010 . \quad$ Disponível em: <http://www.microsoft.com/portugal/presspass/press/2009/abr09/049EstudoConsumo.mspx>. Acesso em: 30 maio 2009.

MUNIZ, Diógenes. Folha Online. Microsoft faz campanha contra o Orkut; Google ironiza ataques. 9 janeiro 2008.2 Disponível em: <http://www1.folha.uol.com.br/folha/informatica/ult124u361596.shtml> Acesso em: 16 novembro 2008. 
ORKUT. Disponível em: <http://pt.wikipedia.org/wiki/Orkut>. Acesso em: 31 maio 2009.

PEPPERS, Don. A empresa um-a-um. Maio 1998. Disponível em: <http://www.perspectivas.com.br/g10.htm>. Acesso em: 23 maio 2009.

RICHERS, Raimar. 0 que é Marketing? São Paulo: Brasiliense, 1986.

ROSSITER, John R.; PERCY, Larry. Advertising and promotion management. 2. ed. Nova York: McGraw-Hill, 1997.

SERRANO, Daniel Portillo. Os 4 Ps do Marketing. Dezembro 2006. Disponível em: <http://www.portaldomarketing.com.br/Artigos/4_Ps_do_Marketing.htm>. Acesso em: 26 maio 2009.

SHIMP, Terense. Propaganda e Promoção: Aspectos complementares da comunicação integrada de marketing. 5. ed. Porto Alegre: Bookman, 2002.

SITE do Guaraná Antarctica Disponível em:

<http://www.guaranaantarctica.com.br/default.aspx>. Acesso em: 30 maio 2009.

VAZ, Conrado Adolpho. Google Marketing: 0 Guia Definitivo de Marketing Digital. 2. ed. São Paulo: Novatec, 2008. 472 p.

VERGARA, Sylvia Constant. Projetos e Relatórios de Pesquisa em Administração. São Paulo: Atlas, 2001.

WALES, Jimmy. Wikipedia is an encyclopedia. 8 março 2005. Disponível em <http://mail.wikipedia.org/pipermail/wikipedia-l/ 2005-March/038102. html>. Acessoem: 25 mai 2009.

WIKIPÉDIA. Disponível em: <http://pt.wikipedia.org/wiki/Wikipedia>. Acesso em: 30 maio 2009.

YOUTUBE Blog Brasil. Disponível em <http://br.youtube.com/blog>. Acesso em: 30 maio 2009.

YOUTUBE. Disponível em <http://pt.wikipedia.org/wiki/YouTube>. Acesso em 30 maio 2009.

1 Estudo da Microsoft "Europe Logs On: Internet Trends of Today and Tomorrow". Cf.http://www.microsoft.com/portugal/presspass/press/2009/abr09/04-9EstudoConsumo.mspx.

2 Propagandas que aparecem na tela do computador de um usuário toda vez que o mesmo acessa um determinado site, sem que o usuário as solicite.

3 Entende-se por Web 2.0 como um termo usado para designar a segunda geração de comunidades e serviços baseados na plataforma web, tal como Wikipédia, redes sociais, blogs e outros.

4 Conforme site da AmBev - http://www.ambev.com.br/not_04.php?noticia=152

5 Dados de 2 de junho de 2009. 
6 Promoção realizada em 2008 que consistia em disponibilizar para os consumidores aparelhos de áudio que, ao encostarem em objetos ocos - como balde, latinha de refrigerante, vaso de plantas, etc. - transformam esses objetos em amplificadores de som.

7 ARG (Alternate Reality Game) é um tipo de jogo que combina as situações de jogo com a realidade, recorrendo às mídias do mundo real, de modo a fornecer aos jogadores uma experiência interativa. 